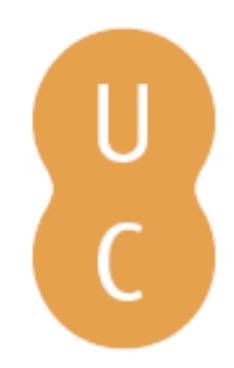

\title{
nombalina
}

\section{Educating the young ... over wine: Plutarch, Calvenus Taurus, and Favorinus as convivial teachers}

\author{
Autor(es): $\quad$ Roskam, Geert \\ Publicado por: Imprensa da Universidade de Coimbra; Centro de Estudos Clássicos e \\ URL \\ persistente: URI:http://hdl.handle.net/10316.2/32021 \\ DOI: $\quad$ DOI:http://dx.doi.org/10.14195/978-989-8281-17-3_34 \\ Accessed : $\quad$ 26-Apr-2023 14:33:22
}

A navegação consulta e descarregamento dos títulos inseridos nas Bibliotecas Digitais UC Digitalis, UC Pombalina e UC Impactum, pressupõem a aceitação plena e sem reservas dos Termos e Condições de Uso destas Bibliotecas Digitais, disponíveis em https://digitalis.uc.pt/pt-pt/termos.

Conforme exposto nos referidos Termos e Condições de Uso, o descarregamento de títulos de acesso restrito requer uma licença válida de autorização devendo o utilizador aceder ao(s) documento(s) a partir de um endereço de IP da instituição detentora da supramencionada licença.

Ao utilizador é apenas permitido o descarregamento para uso pessoal, pelo que o emprego do(s) título(s) descarregado(s) para outro fim, designadamente comercial, carece de autorização do respetivo autor ou editor da obra.

Na medida em que todas as obras da UC Digitalis se encontram protegidas pelo Código do Direito de Autor e Direitos Conexos e demais legislação aplicável, toda a cópia, parcial ou total, deste documento, nos casos em que é legalmente admitida, deverá conter ou fazer-se acompanhar por este aviso.

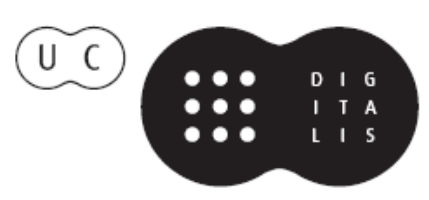




\section{Symposion and Philanthropia in Plutarch}

\section{José Ribeiro Ferreira, Delfim Leão Manuel Troster e Paula Barata Dias (eds.)}

IMPRENSA DA UNIVERSIDADE DE COIMBRA 


\title{
Educating the young ... Over wine? Plutarch, Calvenus TAurus, AND Favorinus as CONVIVIAL TEACHERS
}

\author{
Geert Roskam
}

Catholic University of Leuven

\begin{abstract}
Already in the Archaic period, the symposion was often connected with educational purposes. Plato elaborated his own alternative (esp. in the first two books of the Laws), which in turn influenced later authors. This contribution deals with three such thinkers: Plutarch, Calvenus Taurus, and Favorinus of Arles. All three realised that the context of the symposion yielded interesting opportunities for the education of younger students. I propose to examine their evaluation of their students, their attitude (and, in Plutarch's case, self-characterisation) as a teacher, and their didactic approach. The evidence shows that Plutarch and Taurus basically pursue the same philosophical purposes in their education during dinner, by promoting independent and critical thinking, whereas Favorinus' teaching activities are more in line with the brilliant self-display of the so-called 'Second Sophistic'.

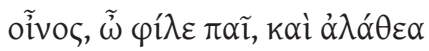

Alcaeus, fr. 366
\end{abstract}

\section{Wine and education: a strange alliance?}

For most people, the Greek symposion probably does not call forth associations with respectable education on a high level. One rather thinks of bacchic dancing and mimes, skolia, relaxed conversation, laughter and friendship, expensive flute-girls ${ }^{1}$ who may also have been hetairai, clowns, acrobats, and jugglers, and in the first place much wine and drunkenness ${ }^{2}$. Several of these elements were part and parcel of the symposion from the very beginning, and once introduced, most of them remained popular until late antiquity. This is not only confirmed in Old Comedy ${ }^{3}$ but also in many passages from later symposium literature.

This, however, is only one side of the picture. Very early in the Greek tradition, the banquet was also connected with educational purposes and could be used as a tool for affirming and rehearsing elite values. In both Crete and Sparta, young boys were in the Archaic period allowed to attend the common meals of their fathers and to listen to their discussions of political and military affairs ${ }^{4}$. The Corpus Theognideum illustrates the same tendency of teaching young boys like Cyrnus in the (pederastic?) context of a symposion ${ }^{5}$, and from Plato on, the educative aspect of the symposion

\footnotetext{
${ }^{1}$ Cf. C. G. Starr, 1978.

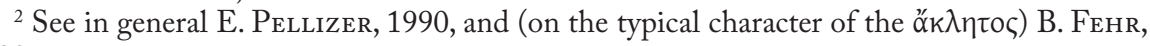

${ }^{3}$ See E. L. Bowie, 1995.

${ }^{4}$ J. N. BREMMER, 1990, pp. 136-7.

${ }_{5}^{5}$ Cf. also W. Rösler, 1995, pp. 109-11.
} 1990. 
is discussed and justified from a philosophical point of view. It is well known that Plato is usually rather critical of the contemporary practices at drinking-parties ${ }^{6}$, but in the first two books of his last work, the Laws, he finally elaborates his own alternative, interpreting symposia as a training in, and a secure test of, temperance $(646 c-650 b)$ and emphasising the close connection between $\pi \alpha 1 \delta \varepsilon i ́ \alpha$ and a well-ordered symposion which is supervised by sober commanders ${ }^{7}$. In a famous passage from a much earlier dialogue, Plato already opposed the symposia of ordinary people

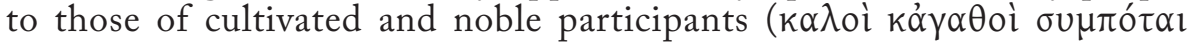

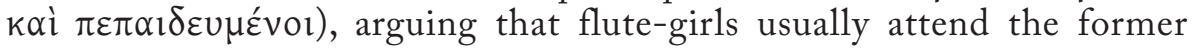
banquets but remain absent from the latter, where the company is able to entertain themselves with their own conversation (Prt. 347c-348a). Well in line with this view, Eryximachus proposes, near the beginning of Plato's Symposium, to bid farewell to the flute-girls and spend the time together in conversation (176e). In Plutarch's Quaestiones convivales, the Stoic Philip of Prusias ${ }^{8}$ perceptively points to the exceptional nature of Agathon's banquet. The company consisted of a small number of learned guests (cf. also 613D), so that "the surprising thing was not that the flute-girl should be expelled from such a company, but that the party was not so entertained and charmed as to forget both food and drink" (710BC; transl. E. L. Minar, slightly modified). The conclusion seems to be that even at more learned banquets some place could be given to popular forms of entertainment, and indeed, Xenophon's Symposium also contains both philosophical conversations and interludes during which a Syracusan company diverts the guests with different performances. On the other hand, when Xenophon depicts the banquets in the Cyropaedia as remarkably sober and devoid of all customary entertainments, he appears to speak normatively rather than descriptively9.

In any case, the Greek tradition of the symposion soon showed a double face. On the one hand, the banquet was a world of heavy drinking and revelry, with all the risks of socially disruptive behaviour. On the other hand, it helped to strengthen social ties and build community (by creating and maintaining friendship and by educating the young towards honourable moral behaviour). My focus on the latter aspect does not necessarily betray my own preferences (which are irrelevant here) but instead illustrates that of the authors who will be discussed. Let us begin, then, with Plutarch.

\footnotetext{
${ }^{6}$ See esp. the thorough discussion of M. Tecusan, 1990. Cf. on Plato's general attitude to wine also P. BoyancÉ, 1951.

${ }^{7}$ See Lg. 641b-d; 642a; 643a; 645c; 652a; 671a-674c.

${ }^{8}$ On Philip of Prusias, see B. Puech, 1992, pp. 4869-70; S.-T.Teodorsson, 1996, pp. 102-3; cf. also D. ВавUт, 1969, pp. 254-60 on the contrast between Philip of Prusias and an anonymous Stoic sophist in Quaest. conv. 710B-711D.

${ }^{9}$ See D. L. Gera, 1993, pp. 150-4.
} 


\section{Plutarch of Chaeronea}

Plutarch was no heavy drinker indeed ${ }^{10}$, and even if he may occasionally have been indulgent with the drinking of several of his heroes ${ }^{11}$, he usually advocates temperance and moderation ${ }^{12}$. This implies that he was by no means a rigid abstainer, and basically the same attitude he adopted towards the customary forms of sympotic entertainment. He deems them pleasant whenever present but refuses to attach great importance to them (cf., e.g., Quaest. conv. 629C) and just like Plato prefers to lay full emphasis on another kind of entertainment, viz. that of erudite discussions. It is from such a pastime that Plutarch's cultivated friends derive their highest pleasures. At Plutarch's dinners, the burlesque clown has to give way to refined humour, the flute-girl to lively conversations about music, and in general, sympotic entertainment tends to coincide to an important extent with relaxed philosophical discussions. The topics for conversation should be adapted to the specific context of the symposion $^{13}$, to be sure, and the argumentative style should likewise reflect the sympotic atmosphere ${ }^{14}$, but the high intellectual level of the company sufficiently guarantees that the discussion never results in trivial platitudes or vulgar bragging.

It is clear that such a context yields interesting opportunities for the education of younger students. And young men do indeed participate in several banquets which Plutarch describes (646A; 653B; 655EF; 676E; 692B; 704E). On these occasions, the conversations also have an educative character, and in that sense, they contain important information about Plutarch's educative ideals and about his practical approach. We may catch a glimpse of the kind of students Plutarch welcomes at his table and of the way in which he judges them, and we may see different teachers at work, not in their school but in a less formal context.

\subsection{The students}

In Plutarch's Quaestiones convivales, the young men are usually characterised in a fairly negative way. First of all, they are easily impressionable. At a banquet which the musician Erato organises in Athens, for instance, the participants use garlands of roses instead of laurel, and when Ammonius begins to criticise this, the young men are much embarrassed and quietly begin to take off their

${ }^{10}$ There is only one passage in the Quaestiones convivales where Plutarch mentions that the party risked to degenerate into drunken behaviour (620A), but even in this case, the company soon turned to intellectual discussions; see on the passage P. A. STADTER, 1999, pp. 483-5.

${ }^{11}$ Such as Cimon (cf. Cim. 4,3 and 15,3) and Cato the Younger (cf. Cat. Mi. 6,1-2); see H. G. INGENKAMP, 1999.

${ }^{12}$ See, e.g., S.-T. Teodorsson, 1999, and A. G. Nikolaidis, 1999.

${ }^{13}$ Accordingly, Plutarch prefers to deal with familiar and non technical issues (see esp. Quaest. conv. 614D-615B), imitating the example of Xenophon (630A).

${ }^{14}$ Here, Plato's Symposium is the model, combining as it does an easy argumentation with concrete examples and myths (Quaest. conv. 614CD). 
garlands (645D-646A). Plutarch immediately makes it clear that such a reaction is unnecessary: Ammonius is just making fun of the company $(645 \mathrm{D}$ : $\dot{\varepsilon} \pi \varepsilon \sigma \kappa \omega \psi \varepsilon)$ and merely introduces the issue for the sake of exercise and inquiry

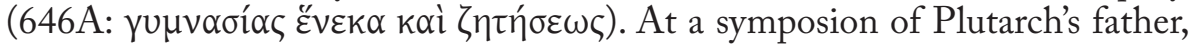
likewise in Athens, the host raises the question of why sweet new wine is least intoxicating $(655 \mathrm{EF})$. Again, most students are embarrassed, coming no further than being baffled by what they regard as paradoxical and incredible $(655 \mathrm{~F})$, although in this case two of them (Hagias and Aristaenetus) do their best to provide a plausible explanation (655F-656A). When Lucanius entertains Plutarch's friends in Corinth, finally, the discussion is about the use of the pine as the victor's garland at the Isthmia. An unnamed professor of rhetoric, well-known for his familiarity with literature, points out that the ancients used celery rather than the pine and argues his point by means of a whole series of quotations $(676 \mathrm{C}-\mathrm{E})$. In this case, too, the young are impressed by the rhetorician's great learning and wide reading $(676 \mathrm{E})$ and once again, one of the older, learned participants (here the host himself) has to intervene in order to put things into perspective $(676 \mathrm{EF})$.

Secondly, young people are - unsurprisingly - still represented as insufficiently acquainted with ancient literature. We already saw how they were impressed by the wealth of quotations adduced by the rhetorician (676E). On another occasion, young men attacked Epicurus for having introduced in his Symposium a discussion about the proper time for coition. In their view, Epicurus gave evidence of extreme licentiousness by dealing with such a topic in the presence of young men and at a banquet (653BC). Such a criticism, however, is not merely cheap but even entirely unjustified, being based on utter ignorance of the great literature of the past - both Xenophon's Symposium (653C) and Zeno's Republic (653E) deal with similar topics - and on a careless interpretation of Epicurus' position. Zopyrus thus undertakes the defence of Epicurus and explains what the great philosopher of the Garden really wanted to say $(653 \mathrm{C}-\mathrm{E})$. As a result, the young men are reduced to silence and the company goes on to discuss precisely this topic.

Thirdly, the young give evidence of radicalness, which may be connected with their fresh enthusiasm for philosophy. When Philinus took some of his students to a banquet of Philo the physician, one of them refused to eat anything but bread (660D). This example is somewhat ambivalent, though, for the student's behaviour is indirectly (and not without humour) attacked by the host and no less indirectly defended by Plutarch and Philinus. The young man's conduct shows a praiseworthy principled consistency, to be sure, but also a rigid inflexibility which hardly suits the sympotic conviviality and

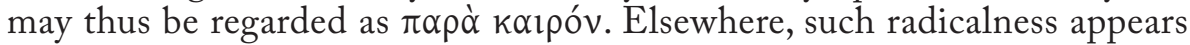
in an even more negative light. At a dinner given by Aristion, the discussion is initiated by Niger. Before reporting the latter's arguments, Plutarch gives a short characterisation of the young man: he happens to have returned from a brief course of instruction under a famous philosopher. The phrase $\chi \rho o ́ v o v$

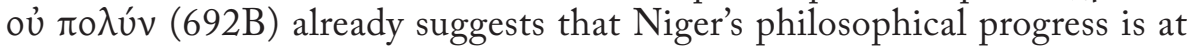


best fairly limited and superficial and thus announces Plutarch's explicit evaluation that the young man has not really comprehended his teacher's doctrines. He has begun, however, to imitate his annoying behaviour by continuously criticising and cross-examining the company. When he launches his attack against the sumptuous preparations which Aristion has made, combining a strongly moralising tone with would-be erudition ${ }^{15}$ (692C-E), we already know that his high-principled radicalness lacks any fundamentum in re. No wonder, then, that the host easily succeeds in refuting his young guest by correcting his mistakes, showing a much higher level of erudition, and demonstrating that the attack is exaggerated and irrelevant (692E-693E).

Finally, hardly anything is said about positive qualities, with one exception, though: the learned company fully appreciates the young men's skill in finding

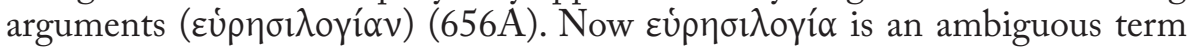
and it has more than once a negative connotation in Plutarch's works. Especially the Stoics are often blamed for their sophistic ingenuities ${ }^{16}$. In this context, however, the word is obviously positive ${ }^{17}$, for Plutarch goes on to praise the fact that the young men looked for proper solutions instead of falling back on more ready answers (656AB). Even this praise, however, remains somewhat

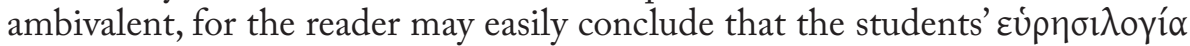
was a dire necessity, rooted in their ignorance of well-known traditional solutions.

The following general conclusions can be derived from the evidence discussed so far. In Plutarch's Quaestiones convivales, the young men [1] usually remain passive. They often undergo the situation and occasionally become themselves the topic of conversation rather than actively contributing to it. [2] They give ample evidence of their immaturity, both by their conduct and by their words, and [3] they do not seem to be full members of the company. Their sincere interest in philosophy and the intellectual and moral level which they have already reached enables them to attend the conversations of Plutarch's learned friends, to be sure, but they are never on a par with the older participants. Plutarch's attitude towards the young students in the Quaestiones convivales, then, shows a curious mix of a condescending depreciation and a prudent appreciation. Plutarch realised very well that his intellectual level, and that of his erudite friends, far surpassed that of the immature and inexperienced $\nu \varepsilon ́ o l$, and in spite of his friendly openness and stimulating remarks, this great distance was never overcome.

It is interesting to compare this characterisation of the young students with that of the $\pi \rho \circ$ oó $\pi \tau \omega v$ ("the man who is making (moral) progress") in

15 According to D. BAвUт, 1969, pp. 252-4, several aspects of Niger's speech show that he went to a Stoic teacher. M. Cuvigny, 1969, p. 565 suggests the interesting possibility that Niger's teacher was none other than Epictetus.

${ }^{16}$ See De aud. poet. 31E; De comm. not. 1070E and 1072F; cf. also De Stoic. rep. 1033B. In all

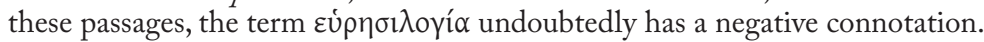

${ }^{17} \mathrm{Cf}$. also Quaest. conv. 625C and 632B. 
De profectibus in virtute. In this treatise, Plutarch lists a series of indications of moral progress: the continuity of one's course, mildness $(\pi \rho \alpha o ́ \tau \eta \varsigma)^{18}$ and lack of jealousy, authenticity, consistency, untroubled dreams, alleviation of the passions, etc. ${ }^{19}$. It is striking that not one of these positive indications returns in the characterisation of the students in the Quaestiones convivales. As far as I can see, there are only two interesting parallels. Near the end of De profectibus in virtute, Plutarch argues that the presence of a certain selfconfidence and self-knowledge can be regarded as a clear token of moral progress. Accordingly, a man who has made such progress will no longer be disturbed when a famous and prudent man suddenly appears, nor conceal or change some personal detail $(85 \mathrm{BC})$, but will even in the presence of good men be satisfied with his own condition. Diametrically opposed to such a behaviour is that of the students who at the dinner of Erato were embarrassed by Ammonius' attack against the use of flower-garlands and began to take them off (646A). Their conduct obviously shows that they have made only little progress and is opposed to that of Plutarch himself, who is not confused at all but quietly and appropriately deals with the situation.

Earlier in the treatise, Plutarch suggests that authenticity ( $\tau$ ò $\pi \rho{ }^{\circ} \varsigma$

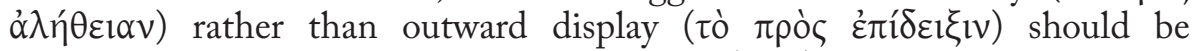
considered as an indication of moral progress $(80 \mathrm{E})$. Whereas beginners are over-bold, give themselves airs, and have a countenance full of disdain which

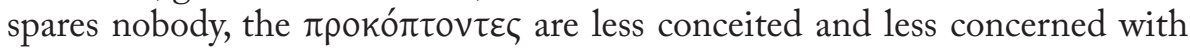
external details, and - what is especially interesting in our context - replace their contempt for other people with biting self-criticism and mildness towards others (81BC). If that is true, Niger can obviously be classified under the group of mere beginners (692B-E), just like the young men who attacked Epicurus (653B). In all of these cases, the students who are introduced in the Quaestiones convivales are negative examples of moral progress. It is clear, then, that a comparison with De profectibus in virtute fully confirms the above conclusions and that the figure of the student in the Quaestiones convivales is usually characterised in a fairly negative way.

\subsection{The teachers}

While the young students all have their own teachers at school, in the context of the symposion, the older participants de facto function together as one group of mutually supporting teachers. Each member of the learned company can take the initiative in contributing directly to the instruction of the young. The host frequently plays an important part in this process by raising interesting questions and directing the discussions, but the guests do not refrain from intervening either, adding new perspectives or

${ }^{18}$ On the crucial importance of this virtue in Plutarch's work, see, e.g., H. M. Martin JR., 1960, and J. De Romilly, 1979, pp. 275-307. On its limitations, see G. Roskam, 2004a.

${ }^{19}$ See G. Roskam, 2005, pp. 220-363 for a systematic discussion of the whole treatise. 
introducing other problems. In that sense, the whole conversation often has an instructive aspect.

In the sympotic context, then, education turns out to be teamwork, and the stimulating exchange of ideas is a win-win situation for teachers and students alike. But this particular context even yields an additional advantage, in that it enables the students to observe the conduct of their distinguished teachers outside the school, in their private life ${ }^{20}$. One should recall in this context the paramount importance which Plutarch attaches to the dynamics of $\mu$ í $\mu$ irs in the educational process ${ }^{21}$. It is well-known that this is one of the crucial motivations behind the ambitious project of the Lives, which offer concrete examples of illustrious men and their honourable accomplishments and thus incite to careful reflection and imitation (see esp. Per. 1,3-2,4 and Aem. 1,1). In De profectibus in virtute, Plutarch likewise argues that active imitation of good examples, even in small details, can be regarded as an indication of moral progress. In this light, the young students who participate in the learned banquets get a unique opportunity. They can watch how their teachers behave in their private life and fashion their own conduct after it. The teachers, on the other hand, appear to function as paradigmatic models, and this aspect of their role in the Quaestiones convivales is a telling example of Plutarch's selfassurance as a teacher.

There are two questions which need further examination in this section: the kind of subjects which the teachers bring forward for discussion and their didactic approach. As far as the former question is concerned, the great variety of subjects immediately attracts notice. All kinds of problems are discussed, with a slight preference for unusual questions (cf. 673A: $\zeta \eta \tau \varepsilon \tilde{v} v$ $\tau l \tau \tilde{\omega} v \pi \varepsilon \rho \imath \tau \tau \tilde{\omega} v)$. Not without reason, the Quaestiones convivales have been linked with the genre of $\pi \rho \circ \beta \lambda \eta n \mu \alpha \tau \alpha^{22}$ (a genre which often occurs in the Corpus Plutarcheum ${ }^{23}$ ), and - equally important in this context - there can also be established a connection with the genre of $\zeta \eta \tau$ n $\mu \alpha \tau \alpha^{24}$ (as exemplified in the Quaestiones Platonicae, which are obviously rooted in Plutarch's teaching activities). These genres interrelate to an important extent, and distinctions are even further blurred by the convivial context, in which education is merely one of the aims (and perhaps not the most important), next to pleasant pastime and creating and maintaining friendship.

The great variety of subjects reflects the broad interests of the company and their accurate observations of details, but also illustrates typical features of the mature philosophical thinking of Plutarch's day, such as the continuous concern to explore and elaborate traditional answers and the sincere attempt

${ }^{20}$ That is, in a context in which they show their real selves; cf. Per. 7,5 and F. B. Titchener, 1999, pp. 496-9.

${ }^{21}$ See, e.g., L. VAn der Stockt, 2005.

${ }^{22}$ See, e.g., S.-T. Teodorsson, 1989, p. 12; cf. also J. Martin, 1931, pp. 173-9.

${ }^{23}$ The Quaestiones Romanae, the Quaestiones Graecae and the Quaestiones naturales are still

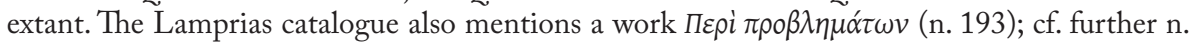
119, 139, 149, 160, 161, and 167. See also G. W. M. Harrison, 2000.

${ }^{24}$ See esp. J. Opsomer, 1996, pp. 75-6. 
to get a grip on even the most trivial details of reality through a rational explanation of their causes. The company does not merely consist of Platonists such as Plutarch and Ammonius, but also of adherents of the Peripatos (e.g. Lamprias), Pythagoreans (e.g. Lucius), Stoics (e.g. Sarapion and Philip of Prusias), and Epicureans (e.g. Boethus and Zopyrus). This philosophical circle is further completed by physicians, poets, rhetoricians, grammarians, mathematicians, and statesmen. Everyone brings along his own expertise and deals with the questions from his own point of view ${ }^{25}$. No doubt every member of the company, however erudite he may be, can benefit from such a conversation ${ }^{26}$. For the students, however, it provides a particularly rich introduction to different domains of the contemporary scientific and philosophical thinking ${ }^{27}$.

The teachers' didactic approach, on the other hand, is fully adapted to the sympotic context, rather than vice versa. Usually the learned company does not seem to bear in mind that the conversation also serves a pedagogical aim. They just go on to entertain themselves through their discussions. The young men can listen silently and attentively, and thus learn a lot. Occasionally, however, the students are invited to make their own contribution. In such cases - which remain fairly rare after all - their self-motivation and independence is stimulated ${ }^{28}$ (646A; 656CD; 744C; 746B; cf. also 694D) and they get the opportunity to secure for themselves a more important place in the company. For a while, the education process appears to become a dialogue. Even at such moments, however, the distance between students and teachers remains and the seeds of the dialogue never reach maturity. The reason for this is not so much the teachers' disdain but rather their friendly tact: the learned company fully takes into account the less advanced level of the students. Therefore Ammonius does not refute Trypho's argument (648B) and later on generously promises to refrain from replying to the solutions proposed by the young men (649A). It is clear that such an attitude, while combining kindness with diplomacy, is hardly conducive to real dialogue. Only twice are the students' contributions explicitly praised as clever and plausible products of personal thinking (656A and 719E). Se non è vero, è ben trovato. And twice indeed, one may well remain sceptical about the value of their position, for in both cases, the praise is immediately followed by instruction: the students are introduced to traditional solutions which are well-known in the school but which they

${ }^{25}$ Only the statesmen cannot take advantage of their political experience, since the subject of politics is usually avoided in the sympotic discussions; cf. S.-T. Teodorsson, 1995.

${ }^{26}$ Passages such like Quaest. conv. 628D and 664D make it perfectly clear that the debates are not merely an exercise for the young men alone.

${ }^{27}$ It may be added in passing that this approach is also in line with Plutarch's sceptical outlook (on which see J. Opsomer, 1998). Different views are often praised as plausible and are more than once juxtaposed without clear hierarchy. The members all look for the truth, without claiming to have reached definitive conclusions. Cf. L. VAn DER Stоскт, 2000, pp. 94 and $97-8$.

${ }^{28}$ See in general G. Rosкам, 2004b, esp. pp. 101-14. 
apparently overlooked or ignored. In that sense, the young men even here fail to become full members of the group.

Similar conclusions, finally, hold for moral topics, which are also discussed. As has been said above, the moral conduct of the company at the banquet serves as a concrete model that is worthy of imitation. Furthermore, the older participants sometimes bear in mind the specific situation and needs of the young. When Olympichus, for instance, advocates complete sexual continence, Soclarus intervenes, pointing to the presence of young married men for whom such an advice is worthless (654C). Finally, if need be, the students are rebuked for their moral shortcomings. When the company occasionally forgets the decorum and joins in disgraceful dancing, Lamprias wishes to rebuke the young men but hesitates because he does not wish to appear as a severe schoolmaster (704C-E). When Callistratus adds fuel to the fire, however, he decides to intervene and elaborates on the moral dangers which rhythmical music entails (705B-706C). This is a beautiful piece of parrhesiastic admonition which still remains friendly and tactful: through his indirect and theoretical approach, Lamprias perfectly succeeds in avoiding direct attacks and disturbing the context of convivial friendship, while at the same time managing to get his message across in an unambiguous and clear way ${ }^{29}$. In this case, too, the same tension between tactful respect and patronising returns.

\section{Calvenus Taurus}

Basically the same approach returns in our sources about Calvenus Taurus, an influential Platonist in Athens whose floruit is placed by Eusebius in 145 A.D. (Chron. 2161; p. $202 \mathrm{Helm}^{30}$ and whose lessons were attended by Aulus Gellius. Gellius' work contains much interesting information about Taurus' pedagogical convictions and ideals. Several passages from his Noctes Atticae show a fairly negative portrait of the students, who in Taurus' view are far inferior to their predecessors (1,9,1-11 and 7,10,1-5). Taurus himself, on the other hand, appears as an erudite teacher who is well acquainted with medicine $(12,5,3$ and $18,10,1-7)$, is respected by powerful politicians $(2,2,1)^{31}$, and always welcomes opportunities for intellectual discussions $(12,5,5)$.

In the context of this contribution, however, it is especially important that Taurus used to invite his students to dinner. Gellius tells how the students were expected to bring topics for discussion as their own contribution to the dinner.

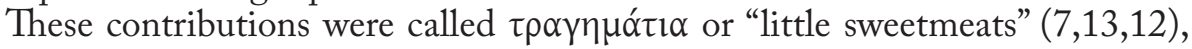
which may be understood both as a humorous allusion to the second book of

${ }^{29}$ A beautiful parallel is to be found in De ad. et am. 70E (Ammonius' indirect rebuke of one of his students).

${ }^{30}$ Good studies of Taurus' life and philosophy include H. Dörrie, 1973; J. Dillon, 1977, pp. 237-47; M.-L. Lakmann, 1995. An edition of the fragments with commentary can be found in A. Giò̀, 2002, pp. 221-376.

${ }^{31}$ Cf. J. Dillon, 2002, pp. 29-30. 
Plato's Republic (372c and e, on the desserts of the 'healthy' and the 'fevered' state) and as a tacit correction of this passage (replacing as it does even the most simple desserts such as figs or beans with pleasant intellectual discussions ${ }^{32}$ ). However that may be, it is clear that Taurus' symposia (at least those mentioned by Gellius) are much more adapted to the specific intellectual condition of students than Plutarch's. Whereas the young students usually remain silent participants in Plutarch, they apparently play a much more important part at Taurus' table.

We might expect, then, that the characterisation of the students which we find in Gellius is more positive too. This, however, is only partly true. Here as well, the young men occasionally appear as immature, and their easy and unjustified rejection of some subtle problems as empty sophisms $(7,13,7)$ recalls the cheap criticism of the young men against Epicurus in Plutarch's Quaestiones convivales (653B) ${ }^{33}$. But in general, Taurus seems to have taken their arguments seriously, although an important caveat should be added here, viz. the differences of perspective in both sources: Plutarch wrote as a teacher, Gellius as a student, and this, of course, in all likelihood influenced their presentation. We shall never know what Taurus really thought about the contributions of his students nor how he behaved in a context comparable to that of Plutarch's learned symposia.

Taurus' didactic approach is very similar to that of Plutarch. For just like Plutarch, Taurus takes care to stimulate the independence and the selfmotivation of his students, and more than Plutarch, he succeeds in turning the educational process into a real dialogue. His invitation to look for intriguing

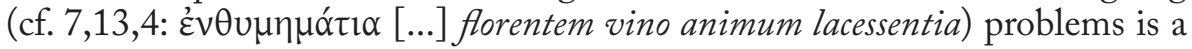
particularly interesting and accurate way of arousing wonder, which constitutes the $\alpha \rho x \eta ́$ of philosophy, and like Plutarch, he does not hesitate to derive himself topics for discussion from concrete events (17,8,3-9). Under Taurus' supervision, the students as it were learn to philosophise. They are allowed to speak first, whereupon Taurus intervenes in order to confirm their answer ${ }^{34}$ $(17,8,11)$, to add supplementary information $(17,8,11-15)$ and raise related questions $(17,8,16)$, or to emend their erroneous views by giving the relevant philosophical background (7,13,7-11).

The general conclusion, then, is that Plutarch and Taurus were both conscious of the rich opportunities which a symposion could provide for educative purposes. The students have a more significant role in Taurus' approach, although this is no doubt connected with the specific context (Taurus' symposia, unlike Plutarch's, were specifically organised for students) and perhaps with the judgement of Gellius. But both Plutarch and Taurus $176 \mathrm{e}$.

${ }^{32}$ Thus following Plato's own ideals of sympotic entertainment; cf. Prt. 347cd and Smp.

${ }^{33} \mathrm{Cf}$. also the figure of the garrulous and boastful Stoic student in 1,2,3-6, who may serve as the counterpart of Niger in Plutarch, Quaest. conv. 692B-E.

${ }^{34}$ Even if he probably disagreed with several aspects of the proposed solution; cf. M.-L. LAKMANN, 1995, p. 158. 
try to stimulate basically the same philosophical attitude by encouraging independent thinking ${ }^{35}$.

\section{Favorinus of Arles}

A completely different case is that of Favorinus, who knew Plutarch personally ${ }^{36}$ and participated in at least one symposion where Plutarch was present as well (Quaest. conv. 734E-735C). But Favorinus also organised symposia himself, and two of these were attended by Gellius ${ }^{37}$. During these dinners, so Gellius tells us, a slave usually read a book. On one such occasion, Favorinus makes a critical remark which immediately closes the debate, even before it has begun $(3,19,1-5)$. The other case is even more illustrative. When in a Latin poem the term Iapyx occurred, the company asks Favorinus to explain this name and add supplementary information about the names of the other winds $(2,22,2)$. Favorinus replies with a torrent of words, going on and on ad nauseam. His speech is a beautiful sample of his encyclopedic erudition ${ }^{38}$, to be sure, but also shows ex cathedra teaching which leaves no place at all for any dialogue. The process is entirely monological, and the students can only remain passive and admire the brilliant speaker in silence. They are never encouraged to think for themselves or adopt an independent and critical position.

It is interesting to note that Favorinus himself seems to realise that his contribution was not entirely comme il faut. At the end of his lengthy speech, he admits that "for one to do all the talking at a large dinner-party is neither decent nor becoming" (2,22,26: in convivio autem frequenti loqui solum unum neque honestum est [...] neque commodum; transl. J. C. Rolfe). These words most strikingly reveal Favorinus' principal concern. His avowal is by no means rooted in an educative reflex but in his insight that a dinner is not the appropriate place to give a speech such like that. His intervention is much more in line with the epideictic speeches characteristic of the so-called 'Second Sophistic', which require another audience and another context. He does not attempt to stimulate independent thinking but wants to impress the audience through his erudition and through the literary embellishment of his words. In that sense, Gellius' reference to Favorinus' elegantia verborum and to his beautiful style $(2,22,27)$ is far from pointless. For Taurus, this would have been of minor importance $(17,20,5-6)$, but for Favorinus, it was essential. It is clear, then, that

${ }^{35}$ One may well wonder whether Taurus read Plutarch's Quaestiones convivales and drew inspiration from the work for his didactic approach, or whether the similarities should rather be traced back to the Platonic philosophical tradition which they both share. For Taurus' general appreciation of Plutarch (cf. 1,26,4: Plutarchus noster, vir doctissimus ac prudentissimus), see, e.g., J. Dillon, 1977, p. 237; M.-L. Lakmann, 1995, pp. 227-8.

${ }^{36}$ On the philosophical connections between both, see, e.g., J. Opsomer, 1997.

${ }^{37}$ On Gellius' importance as a source for Favorinus, see M.-L. Lakmann, 1997; S. M. Beall, 2001; cf. also B. Baldwin, 1973 and M. Pezzati, 1973.

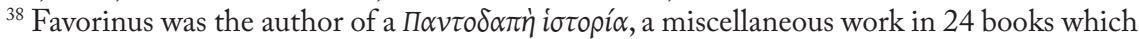
gives evidence of his encyclopedic interests; see further A. BARIgAzzI, 1993, pp. 568-70 and L. Holford-Strevens, 1988, pp. 81-3. 
Favorinus' education is aimed at a different ideal. Unlike Plutarch and Taurus, he does not wish to educate mature Platonic philosophers, but self-conscious, erudite, and virtuoso speakers such like himself.

\section{Conclusion}

The above evidence clearly shows that the symposion did not necessarily coincide with drunken revelry in the intellectual circles of the first and second century A.D. It was especially regarded and appreciated as a pleasant pastime which tightened the bonds of friendship, but at the same time, it yielded rich opportunities for the education of younger men. In the convivial context, these educative purposes sometimes came to the fore (viz. in the banquets which Taurus organised for his students), and sometimes merely played a secondary part in a broader context (as in Plutarch's Quaestiones convivales). In all of the above discussed cases, however, the sympotic conduct of both teachers and students gives evidence of the triumphant victory of refined culture over refined wine.

\section{WORKS CITED}

Babut, D., Plutarque et le stoïcisme, Paris, 1969.

Baldwin, B., "Aulus Gellius and his Circle”, AClas, 16 (1973) 103-7.

Barigazzi, A., "Favorino di Arelate", $A N R W$ II, 34, 1, Berlin - New York, 1993, pp. 556-81.

Beall, S. M., "Homo fandi dulcissimus: The Role of Favorinus in the Attic Nights of Aulus Gellius", AJPh, 122 (2001) 87-106.

Bowie, E. L., "Wine in Old Comedy", in O. Murray \& M. Tecusan (eds.), In vino veritas, London, 1995, pp. 113-25.

BoyancÉ, P., "Platon et le vin”, BAGB, 4 (1951) 3-19.

Bremmer, J. N., “Adolescents, Symposion, and Pederasty”, in O. Murray (ed.), Sympotica. A Symposium on the Symposion, Oxford, 1990, pp. 135-48.

Cuvigny, M., "Plutarque et Épictète", in Actes du VIII Congrès de l'Association Guillaume Budé (Paris, 5-10 Avril, 1968), Paris, 1969, pp. 560-6.

De Romilly, J., La douceur dans la pensée grecque, Paris, 1979.

Dillon, J., The Middle Platonists. A Study of Platonism 80 B.C. to A.D. 220, London, 1977.

"The Social Role of the Philosopher in the Second Century C.E.: Some Remarks", in P. A. Stadter \& L. Van der Stockt (eds.), Sage and Emperor. Plutarch, Greek Intellectuals, and Roman Power in the Time of Trajan (98-117A.D.), Leuven, 2002, pp. 29-40. 
Dörrie, H., "L. Kalbenos Tauros. Das Persönlichkeitsbild eines platonischen Philosophen um die Mitte des 2. Jahrh. n. Chr.", Kairos, 15 (1973) 2435 [repr. in Idem, Platonica minora, München, 1976, pp. 310-23].

Fenr, B., "Entertainers at the Symposion: The Akletoi in the Archaic Period", in O. Murray (ed.), Sympotica. A Symposium on the Symposion, Oxford, 1990, pp. 185-95.

Gera, D. L., Xenophon's Cyropaedia. Style, Genre, and Literary Technique, Oxford, 1993.

Giok̀, A., Filosofi medioplatonici del II secolo D.C. Testimonianze e frammenti. Gaio, Albino, Lucio, Nicostrato, Tauro, Severo, Arpocrazione. Edizione, traduzione e commento, Napoli, 2002.

Harrison, G. W. M., "Problems with the Genre of Problems: Plutarch's Literary Innovations", $C P h, 95$ (2000) 193-99.

Holford-Strevens, L., Aulus Gellius, London, 1988.

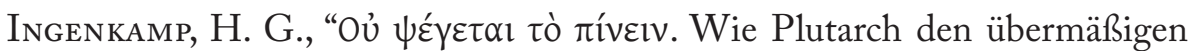
Weingenuß beurteile", in J. G. Montes Cala et al. (eds.), Plutarco, Dioniso y el vino. Actas del VI Simposio español sobre Plutarco (Cádiz, 14-16 de Mayo, 1998), Madrid, 1999, pp. 277-90.

Lakmann, M.-L., Der Platoniker Tauros in der Darstellung des Aulus Gellius, Leiden/New York/Köln, 1995.

"Favorinus von Arelate. Aulus Gellius über seinen Lehrer",in B. Czapla ET AL. (eds.), Vir bonus dicendi peritus. Festschrift für Alfons Weische zum 65. Geburtstag, Wiesbaden, 1997, pp. 233-43.

Martin Jr., H. M., “The Concept of Praotes in Plutarch's Lives”, GRBS, 3 (1960) 65-73.

Martin, J., Symposion. Die Geschichte einer literarischen Form, Paderborn, 1931.

Nikolaidis, A. G., "Plutarch's Attitude to Wine", in J. G. Montes Cala ET Al. (eds.), Plutarco, Dioniso y el vino. Actas del VI Simposio español sobre Plutarco (Cádiz, 14-16 de Mayo, 1998), Madrid, 1999, pp. 33748.

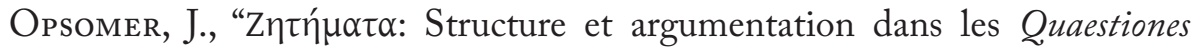
Platonicae", in J. A. Fernández Delgado \& F. Pordomingo Pardo (eds.), Estudios sobre Plutarco: Aspectos formales. Actas del IV Simposio Español sobre Plutarco (Salamanca, 26 a 28, Mayo, 1994), Salamanca, 1996, pp. 71-83.

"Favorinus versus Epictetus on the Philosophical Heritage of Plutarch. A Debate on Epistemology", in J. M. Mossman (ed.), Plutarch and his Intellectual World. Essays on Plutarch, London, 1997, pp. 17-39. 
In Search of the Truth. Academic Tendencies in Middle Platonism, Brussel, 1998.

Pellizer, E., "Outlines of a Morphology of Sympotic Entertainment”, in O. Murray (ed.), Sympotica. A Symposium on the Symposion, Oxford, 1990, pp. 177-84.

Pezzati, M., “Gellio e la scuola di Favorino”, ASNP, 3 (1973) 837-60.

Puech, B., "Prosopographie des amis de Plutarque", ANRW II, 33, 6, Berlin/ New York, 1992, pp. 4831-93.

Rosкam, G., "Plutarch on Self and Others", AncSoc, 34 (2004) 245-73 [= 2004a].

"From Stick to Reasoning. Plutarch on the Communication between Teacher and Pupil”, WS, 117 (2004) 93-114 [=2004b].

On the Path to Virtue. The Stoic Doctrine of Moral Progress and its Reception in (Middle-)Platonism, Leuven, 2005.

Rösler, W., "Wine and Truth in the Greek Symposion”, in O. Murray \& M. TEcusan (eds.), In vino veritas, London, 1995, pp. 106-12.

Stadter, P. A., "Drinking, Table Talk, and Plutarch's Contemporaries", in J. G. Montes Cala et Al. (eds.), Plutarco, Dioniso y el vino. Actas del VI Simposio Español sobre Plutarco (Cádiz, 14-16 de Mayo, 1998), Madrid, 1999, pp. 481-90.

Starr, C. G., "An Evening with the Flute-Girls”, PP, 33 (1978) 401-10.

Tecusan, M., "Logos Sympotikos: Patterns of the Irrational in Philosophical Drinking: Plato Outside the Symposium", in O. Murray (ed.), Sympotica. A Symposium on the Symposion, Oxford, 1990, pp. 23860.

Teodorsson, S.-T., A Commentary on Plutarch's Table Talks, vol. I, Göteborg, 1989.

"La politica nelle Questioni conviviali", in I. GAllo \& B.ScArdigli (eds.), Teoria e prassi politica nelle opere di Plutarco. Atti del V Convegno plutarcheo (Certosa di Pontignano, 7-9 Giugno, 1993), Napoli, 1995, pp. 433-7.

A Commentary on Plutarch's Table Talks. Vol. III (Books 7-9), Göteborg, 1996.

"Dionysus Moderated and Calmed: Plutarch on the Convivial Wine", in J. G. Montes Cala et Al. (eds.), Plutarco, Dioniso y el vino. Actas del VI Simposio español sobre Plutarco (Cádiz, 14-16 de Mayo, 1998), Madrid, 1999, pp. 57-69. 
Titchener, F. B., "Everything to do with Dionysus: Banquets in Plutarch's Lives", in J. G. Montes Cala et al. (eds.), Plutarco, Dioniso y el vino. Actas del VI Simposio español sobre Plutarco (Cádiz, 14-16 de Mayo, 1998), Madrid, 1999, pp. 491-9.

Van der Stockt, L., "Aspects of the Ethics and Poetics of the Dialogue in the Corpus Plutarcheum", in I. Gallo \& C. Moreschini (eds.), I generi letterari in Plutarco. Atti del VIII Convegno plutarcheo (Pisa, 2-4 Giugno, 1999), Napoli, 2000, pp. 93-116.

"The Sting of Ambition: Plutarchan Reflections on Mimetical Behaviour", in M. Jufresa et AL. (eds.), Plutarc a la seva època: Paideia $i$ societat. Actas del VIII Simposio Español sobre Plutarco (Barcelona, 6-8 de Noviembre, 2003), Barcelona, 2005, pp. 139-44. 